\author{
Вадим Слюсар, \\ кандидат філософських наук, доцент, \\ доцент кафедри філософії та політології \\ Житомирського державного університету імені Івана Франка \\ ORCID: 0000-0002-5593-0622 \\ vadmyks1@gmail.com \\ Маріуш Маршевський, \\ кандидат історичних наук $(\mathrm{PhD})$, доцент, \\ науковий співробітник відділу Туреччини, Кавказу та Центральної Азії \\ Центру Східних досліджень (м. Варшава) \\ mar.marszewski@gmail.com
}

\title{
PR-ДІЯЛЬНІСТЬ У РЕЛІГІЙНІЙ СФЕРІ ЯК СКЛАДОВА СОЦІАЛЬНОЇ ДІЯЛЬНОСТІ: ДОСВІД УКРАЇНИ ТА ПОЛЬЩІ
}

У статті розкривається специффіка PR-діяльності релігійних організацій, спрямованої як на їх прихильників, так і громадськість загалом. Також проаналізовано PR-діяльність у галузі культури як складову PR-діяльності релігійних організацій, щуо реалізується у двох аспектах: як меценатство та як інтеркультурна масова комунікащія. Проаналізовано основні канали здійснення PR-діяльності, зокрема онлайн-каналами у формах "диджиталізованого PR",

"Iнтернет-PR" $i$ "cluetrain-PR".

Ключові слова: діяльність, PR-діяльність, релігійна організація, інтеркультурна комунікачія, масова комунікація, "диджиталізований $P R^{\prime}$, "Інтернет-PR", "cluetrain-PR".

\section{Slusar Wadym, Marszewski Mariusz. PR-aktywność w sferze religijnej jako element dzialalności} spolecznej: doświadczenie Ukrainy i Polski.

Artykut ujawnia specyfikę działań PR organizacji religijnych, skierowanych zarówno do ich zwolenników, jak $i$ całego społeczeństwa. W artykule zostały przeanalizowane także działania PR $w$ sferze kultury jako element aktywności PR organizacji religijnych, realizowany $w d w o ́ c h$ aspektach: jako patronat i jako międzykulturowa komunikacja masowa. Przebadano główne kanaty działalności PR, w tym kanaty online w postaci "zdigitalizowanego PR" $i$ "PR internetowego" oraz "cluetrain-PR".

Stowa kluczowe: aktywność, działalność PR, organizacja religijna, komunikacja międzykulturowa, komunikacja masowa, "zdigitalizowany PR", "Internet-PR", "cluetrain-PR".

Slyusar Vadym, Marszewski Mariusz. PR-activity in the religious sphere as a component of social activity: experience of Ukraine and Poland.

The article reveals the specificity of PR-activities of religious organizations aimed at both their supporters and public at large. If the former involves the production of identity markers with this religious community, the symbolic exchange between members of the organization, the updating

and mobilization of their activities, then the focus of PR activities on the public is aimed at establishing a dialogue between believers and secular members of the society. PR activities in this context are intended, on the one hand, to provide the public with knowledge about the functioning of a particular religious activity: both general (theoretical basics, symbols of faith, ritual, religious holidays, etc.), as well as specific events with community life (e.g., as religious holidays were held, ceremonies were performed, charity events were held). On the other hand, to establish public communication with the aim of forming a positive image, revealing stereotypical ideas that destroy it. One of the most widespread types of such PR-activity is broadcasting of worship services and 
sermons, which is aimed, firstly, at the mass involvement of particular confession believers in the performance of religious rituals, and secondly, on the institutional realization of the publicity principle in activity of church as a social organization. It also analyzes $P R$-activities in the sphere of culture as a component of PR-activities of religious organizations, which is realized in two aspects: as patronage and as intercultural mass communication. The main channels of PR-activity realization are analyzed: television and Internet resources. Feature of PR-activity of religious organizations is the functioning of separate religious, or more precisely confessional, television channels. The specificity of such channels is their information and educational orientation, which implies restrictions on entertainment content and talk shows. PR-activity of online channels is carried out in the forms of "digitalized $P R$ " and "Internet-PR", which provide monologous communication, and "cluetrain-PR" - dialogical. The channel of $P R$ activities of religious organizations, which integrates television and the Internet, is YouTube channels, which are less resource-intensive than television and have a large branched regional network.

Key words: activity, PR-activity, religious organization, intercultural communication, mass communication, "digitalized $P R$ ", "Internet-PR", "cluetrain-PR".

Постановка проблеми в загальному вигляді та її зв'язок із важливими науковими й практичними завданнями. Сучасні глобалізаційні процеси, які супроводжуються структуруванням міжкультурних зв'язків, суттєво розширюють сфери та простір діяльності релігійних організацій, що позначається зростанням, з одного боку, рівня горизонтальної мобільності їх суб'єктів, та конкурентної взаємодії між ними, з іншого. Про це свідчать збільшення кількості прозелітів, функціонування великої кількості релігійних засобів інформації, передусім телевізійних каналів супутникового телебачення та спеціалізованих сайтів, поява офіційно зареєстрованих релігійних організацій тих церков, яких до цього не було в певних культурних регіонах. Важливою складовою діяльності релігійних організацій у сфері масової комунікації $\epsilon$ PR- та рекламна діяльності, спрямовані не лише на популяризацію віровчень, але й на формування відповідного іміджу організації й духовного лідера. Значною проблемою для функціонування релігійних організацій є упередженість, недостовірність і навіть використання маніпулятивних практик при висвітленні їх діяльності в засобах масової інформації. Це стосується релігійних організацій, які, по-перше, мають закритий чи відносно закритий характер діяльності, та, по-друге, які динамічно розширюють ареал своєї діяльності. Відтак, будь-які дії представників цих організації стигматизуються мас-медіа маркерами ксенофобії. Зміна характеру взаємодії між самим релігійними організаціями чи у векторі "держава- церква" засобами масової комунікації актуалізує проблему пошуку адекватних до цілі встановлення консенсусу та утилітарних зв'язків соціальних інструментів. Одним з них є PR-діяльність.

Аналіз основних досліджень і публікацій із зазначеної проблеми. Нині в науковій літературі проблема PR-діяльності релігійних організацій розглядається переважно в предметному полі окремих наук. Так, у соціальній філософії аналізується переважно проблема маніпуляції масової свідомості, медіанасилля, у релігієзнавчій - діяльності релігійних організацій, у журналістиці - інструменти реклами та PR, аналізується діяльність релігійних ЗМІ. Зокрема, Ю. Габермас розкрив характер публічної діяльності релігійних організацій, Ш. Гаммер - PR-діяльності в контексті інтеркультурної комунікації, К. Мерле дослідив новітні PR-технології, які вони використовують, В. Солодов здійснив системний аналіз PR-діяльності Римо-католицьких релігійних організацій Франції, У той час, як окреслена нами проблема потребує передусім дослідження в міжпредметній площині. Це дозволить з'ясувати специфіку та характер PR-діяльності релігійних організацій та визначити принципи відбору інструментів.

Метою статті $є$ визначення основних напрямів здійснення PR-діяльності релігійними організаціями на основі досвіду України та Польщі. 
Виклад основного матеріалу 3 обгрунтуванням отриманих наукових результатів. Визначення сутності PR-діяльності як складової соціальної діяльності потребує визначення змісту понять "діяльність", "PR-діяльність", "PR". Зокрема, український учений C. Кримський визначав діяльність як форму активності, яка характеризує здатність людини чи пов'язаних 3 нею систем бути причиною змін у бутті [12, с. 163]. Діяльність характеризується цілеспрямованістю в зміні та перетворенні світу суб'єктом. А відтак, як відзначають О. Огурцов та Е. Юдін, будь-яка діяльність містить у собі такі складові: мету, засоби, результат і сам процес, а ії невід’ємною характеристикою є усвідомлюваність [14, c. 633]. Діяльність у соціальному житті має різні форми, однією з яких є PR-діяльність. Хоча елементи цієї форми притаманні всій історії людства, системного характеру вона стала набувати лише в останнє століття, з початком функціонування спеціальних відділів на різних підприємствах та в організаціях, основним завданням яких був цілеспрямований вплив на громадську думку. Економічні запити на цей вид діяльності спричинив утвердження цього виду діяльності як професійного. Відповідно до зміни ролі PR-діяльності можна зазначати i про тенденцію зміни змісту поняття "PR". Останнє тлумачиться передусім як "управління комунікацією між організацією та іiі громадськістю" [2, с. 4]. Але в контексті становлення інформаційного суспільства варто говорити про зміщення акцентів з управлінської функції на комунікативну. Предметом PR постають суспільні процеси та відносини, у той час як PRдіяльність $є$ засобом впливу на ці процеси задля діалогу між ланками суспільства 3 метою досягнення громадянського консенсусу [13, с. 14]. Цей вид соціальної діяльності спостерігається як у комерційній сфері, так і в соціальному управлінні, політичній практиці, духовному виробництві. PR-діяльність складається з комплексу конкретних PR-дій, метою яких є забезпечення оптимальної взаємодії релігійної організації з громадськістю. Водночас надання PR-діям планомірного характеру дозволяє здійснювати PR-кампанію як складову PR-діяльності, яка може спрямовуватися на вирішення певного конкретного завдання чи на вирішення незапланованих проблем, спричинених кризою чи форс-мажорними обставинами [18, с. 5]. Релігійні організації створюють відповідні структурні підрозділи, які функціонально забезпечують розробку та супровід PR-кампаній. Зокрема, одним з ключових завдань, які проголошені одним 3 таких підрозділів- Патріаршою радою соціальних комунікацій Української греко-католицької церкви, - "розроблення стратегічних цілей комунікації УГКЦ, а також опрацювання комунікаційних моделей реагування на кризові ситуації та виклики" [11]. Зазначимо, що цими обставинами можуть бути законні та підзаконні акти, які змінюють механізми взаємодії державно-церковних відносин, впливають на характер міжконфесійних відносин і т. д. У цій ситуації PR-діяльність дозволяє як зробити публічною позицію релігійних організацій, так і через мобілізацію громадськості (при чому, $\mathrm{i}$ віруючих, і секулярних членів суспільства) вплинути на результат прийняття чи неприйняття рішення.

B. Солодов, аналізуючи PR-діяльність католицької церкви, звертає увагу на суперечливий характер іiї взаємодії із засобами масової комунікації. Зокрема він наголошує, що мас-медіа символізують сучасність та стрімкий розвиток, а релігія - світ традицій, виконуючи при цьому схожі функції; це призводить до часткового витіснення першими із соціального простору релігійної інституції через конструювання власних сучасних ритуалів, виконання функції символічного виробництва [17]. Така тенденція актуалізувала необхідність релігійними організаціями як освоєння новітніх інструментів PR-діяльності, так і реалізацію останньої комплексно, розробляючи цілісні PR-стратегії.

Важливим акцентом у змісті поняття "PR" $є$ публічність, тобто це не просто робота 3 громадськістю у формі послань, звернень, меседжів, а й здійснення діяльності організації за принципом загальнодоступності інформації про ії зміст і специфіку. Відтак, нині з розвитком й тотальним впровадженням і тотальною мобілізацією Інтернет-технологій формується особлива медіареальність, у якій публічність та загальнодоступність стають нерозрізнюваними. Перехід організації суспільного життя від рівня локального контролю за 
порядком та дисципліною до орвелівського та фукіанського постпаноптикуму призводить до зміни характеру PR-діяльності [16]. Важливо, що функціонування паноптичної системи здійснюється деперсонізовано, тобто велика кількість анонімних спостерігачів та наглядачів формує в об'єктів спостереження відчуття, що за ними постійно спостерігають [10, с. 53]. I навпаки, застосування будь-яких інструментів обмеження можливостей спостереження спричиняє реакцію недовіри та підозрілості в громадськості. Ураховуючи цю специфіку, PRдіяльність цілеспрямовано створює ілюзію всепроглядності (напр., система "прозорих офісів", розміщення неформальних фото під корпоративними хештегами i / або чекіном в локації організації).

Саме цей принцип у PR-діяльності релігійних організацій є конфліктогеном, оскільки він заперечує суть утаємничення. Трансляції Богослужінь донедавна здійснювалися в основному телебаченням лише в ключові релігійні свята й часто з участю політичних лідерів держави. Зокрема 3 метою акцентувати увагу на поліконфесійності українського суспільства та домінування в державно-церковних відносинах 19 квітня 2009 року Президент Віктор Ющенко та Прем'єр-міністр Юлія Тимошенко відвідали святкове богослужіння в 4 церквах та соборах по черзі: Володимирському кафедральному соборі, Соборі Василія Великого, Кафедральному соборі Святого Апостола Андрія Первозваного та в Свято-Успенській Києво-Печерській лаврі [19]. Тут водночас спостерігаємо інтеграцію релігійної та політичної PR-діяльностей. Іншим аспектом є розширення цієї інтеграції за рахунок особистого PR, що супроводжується обговоренням вбрання політиків та членів їх родин (напр., у центрі уваги відвідання пасхального богослужіння Президентом Польщі в нинішньому році стали високі рожеві підбори та коротке яскраве пальто [1]), проведенням благодійних чи соціальних акцій.

Масове ж застосування технологій безперервної трансляції онлайн (чи телебаченням, чи через Інтернет-ресурси) дозволяє робити публічною не лише колективну молитву, але й індивідуальну. По суті сфера публічності в такій формі може певною мірою впливати на утаємничений характер деяких релігійних ритуалів. Утім наразі немає підстав стверджувати про утвердження такого інструменту публічності, радше про початковий етап установлення такої тенденції. Так, нині існує практика безперервної трансляції з мечеті аль-Харам у Мецці (напр., на ютуб-каналі "Haramain Support" (вкладка "Makkah Live HD")) та мечеті ан-Набаві у Медині (напр., на ютуб-каналі "AlQuranHD"), з Ватикану (на ютуб-каналі "Vatican News"). B Україні нині здійснюються лише спроби безперервної трансляції, зокрема на ютуб-каналі "Почаев-трансляция".

PR-діяльність має дві спрямованості: на прихильників церкви та громадськість загалом. Якщо перша передбачає продукування маркерів ідентичності з цією релігійною спільнотою, символічний обмін між членами організації, актуалізація та мобілізація їх діяльності, то спрямованість PR-діяльності на громадськість має на меті встановлення діалогу між віруючими та секулярними членами соціуму. Це стосується передусім демократичних суспільств, у яких проголошується відокремлення церкви й держави, актуалізуючи цим роль неформальних каналів комунікації. Юрген Габермас зазначав, що представники обох зазначених спільнот можуть виконувати нормативні очікування відносно ролі ліберальних громадян лише за умови, що вони виконують певні когнітивні передумови і навіть взаємно приписують один одному відповідні епістемічні установки, які набуваються лише у взаємних "навчальних процесах", позбавлених впливу держави [3, c. 124]. PR-діяльність у цьому контексті покликана, з одного боку, дати громадськості знання про функціонування конкретної релігійної діяльності: при чому як загальнотеоретичні (про основи віровчення, символи віри, обрядовість, релігійні свята і т. і.), так і про конкретні події з життя громади (напр., як проходили релігійні свята, здійснювалися обряди, які відбувалися благодійні акції). 3 іншого боку, - установити зворотній комунікаційний зв'язок з громадськістю 3 метою формування позитивного іміджу, виявлення стереотипних уявлень, які його руйнують. Одним з найпоширеніших видів такої PR-діяльності є трансляція богослужінь та 
проповідей, яка спрямована, по-перше, на масове долучення віруючих конкретної конфесії до здійснення релігійних ритуалів, а по-друге, - на інституціональну реалізацію принципу публічності в діяльності церкви як соціальної організації.

Складовою PR-діяльності релігійних організацій є PR-діяльність у сфері культури. Вона реалізується у двох аспектах: як меценатство та як інтеркультурна масова комунікація. Перше передбачає безкорисливе покровительство освіти та культури, що виражається в спонсорській підтримці культурно-мистецьких акцій релігійної спрямованості або проведення власних акцій.

Друге $є$ супровідним глобалізаційних, зокрема міграційних, процесів. Поява в соціальному просторі достатньої для самоорганізації кількості представників різних вірувань природно спричиняє взаємодію та інтеркультурну комунікацію в етнічному та релігійному аспектах. Утім, збільшення інтенсивності міграційних процесів та поява новітніх засобів масової комунікації актуалізують необхідність комплексної PR-діяльності, особливо в містах, у яких мігранти складають понад третину населення. Наукові дослідження цієї та дотичної до неї проблем якраз і ускладнені проникненням великих масивів медіапродукції на тему мігрантів, ксенофобії, ісламофобії в науковий дискурс. Наукові дискусії потрапляють у пастку скандалізації (за В. Гайтмейєром та Дж. Хейгеном), яка полягає в проникненні в нього сенсаційного лексикону, що розповсюджується в засобах масової інформації. Саме тому основна задача PR-діяльності- встановлення та здійснення інтеркультурної комунікації, руйнування стереотипів (на кшталт "усі мусульмани - терористи" чи "католицька церква не вибачилася за христові походи"). Фактично сьогодні відбувається відхід від релігійноетичного плюралізму до релігійно-культурного, основним принципом якого є акцент не на морально-етичних відмінностях у фундаментальних соціальних та політичних дискурсах, а на культурних відмінностях у способі життя [4, с. 171-172]. Міжрелігійний діалог потребує насамперед формування інтеркультурної комунікації. Інтеркультурна PR-діяльність, зокрема, передбачає демонстрацію етнічної та релігійної різноманітності як соціальної нормальності, орієнтацію в зображенні міграції чи інтеграції за принципом активного прийняття; дотримання принципу врівноваженого балансу [5, с. 30-31]. Тому під егідою релігійних організацій проводяться культурно-мистецькі акції. Так, наприклад, за даними порталу "Релігійно-інформаційна служба України" в другій половині 2019 року в Україні було проведено Всеукраїнський конкурс читців Корану в Києві; акція "Іслам - мир", під час якої мусульмани зібралися в саду Шевченка в Харкові для того, щоб ознайомити жителів міста із власними культурними й релігійними традиціями; Літній курс у буддистському Ретритному Центрі Минківка 3 програмою 3 подорожуючим учителем Діамантового шляху з Польщі Войтеком Трацевським та ін.

Здійснення PR-діяльності релігійними організаціями характеризується багатоканальністю. При цьому канал безпосередньої комунікації залишається провідним, незважаючи на можливості використання цілого комплексу опосередкованості. Це можна пояснити, поперше, установкою на долучення віруючих до проведення богослужінь, колективних молитов, а, по-друге, функціонуванням спеціальних комунікативних центрів, якими, по суті, і є церкви, храми, собори, молитовні доми, мечеті, культурні центри і т. д. Тож комунікація здійснюється як вербально через проповіді, сповідь, спілкування 3 духовною особою, так $\mathrm{i}$ невербально - через символічний обмін, мистецькі твори, музику.

Основними каналами масової комунікації в PR-діяльності релігійних організацій, як i багатьох інших видів діяльності, виступають телебачення та Інтернет-ресурси. Особливістю PR-діяльності релігійних організацій $є$ функціонування окремих релігійних, а точніше конфесійних, телевізійних каналів. Специфікою таких каналів $\epsilon$ їх інформаційнопросвітницька спрямованість, що передбачає обмеження розважального контенту та токшоу (окрім каналів протестантських релігійних організацій), акцент на культурних передачах, документалістиці та передачах для дітей. Специфічним контентом на цих телеканалах є богословські передачі, у яких роз'яснюються релігійні настанови та 
тлумачаться положення релігійних текстів. При цьому метою є не лише охоплення віруючих конкретних конфесій, але й представників інших чи позаконфесійних. Основними релігійними телеканалами в Україні є "Глас" (УПЦ), "Телебачення Віковічного слова" (РКЦ), "Живе ТБ" та Телестудія "Апостол" (УГКЦ), протестантські ресурси "Надія", "CNL", "Перекресток.tv" та телевізійна студія "Еммануїл" [15, с. 55]. А також в останні роки почав трансляцію "Новий християнський" канал. Провідні польські релігійні канали - католицький "Телебачення Trwam" та "TBN Polska", який позиціонує себе як сімейний канал 3 християнськими цінностями [8].

Водночас альтернативним каналом PR-діяльності релігійних організацій є ютуб-канали, які $\epsilon$ менш ресурсозатратними на відміну від телебачення й мають значну розгалужену регіональну мережу. Аналіз контенту ютуб-каналів релігійних організацій України та Польщі дозволяє зробити висновок, що, по-перше, вони мають обмежену аудиторію (про це свідчить кількість підписників та переглядів), по-друге, основними відеоматеріалами $\epsilon$ репортажі та духовно-просвітницькі передачі, по-третє, майже відсутні трансляції наживо. Цікавою $є$ тенденція розвитку ютуб-каналів, які висвітлюють діяльність регіональних підрозділів релігійних організацій. Так, для порівняння зазначимо, що канал "СвятоМихайлівський кафедральний собор м. Житомира" станом на кінець 2019 року має понад 6,7 тис. підписників з наповнюваністю контенту в середньому 15 відеоматеріалів щомісяця, у той час як канал "Православна Церква України" - понад 600 (до 5 відеоматеріалів щомісяця).

PR-діяльність онлайн-каналами здійснюється у формах "диджиталізованого PR" та "Інтернет-PR", які передбачають монологічну комунікацію. Для першої форми властиве створення статичної веб-сторінки, у якій висвітлюються структура та цілі організації, оцифровані друковані видання, нерегулярне оновлення стрічки новин. Прикладом реалізації "діджиталізованого PR" $є$ сторінки Польської автокефальної православної церкви (https://www.orthodox.pl/), Української лютеранської церкви (http://ukrlc.org/). "Iнтернет-PR" використовує елементи зворотного зв'язку через заповнення формулярів, опитування, посилання на соціальні мережі. Найпоширенішим каналом здійснення PR-діяльності нині $\epsilon$ офіційна веб-сторінка релігійних організацій та їх структурних підрозділів окремо. За змістом іiі контент близький до контенту некомерційних організацій і виступає офіційним джерелом інформацій для мас-медіа.

Водночас низка дослідників, зокрема Томас Плайл, Крістін Мерле, стверджують про появу нової форми PR-діяльності- "cluetrain-PR", у якій передусім використовується соціальна мережа в якості сфери взаємодії між комунікативними партнерами [7, с. 393]. Поняття "cluetrain-PR" є похідним від "The Cluetrain Manifesto", який проголошено в 1999 році у формі 95 тез, у яких акцентовано на потребах індивідів у нових формах комунікативної взаємодії. Зокрема зазначалося, що навіть у найгіршому випадку наша нова розмова $\epsilon$ цікавішою за більшість промислових виставок, видовищнішою за будь-який телевізійний ситком i, безумовно, ближчою до реального життя, ніж корпоративні веб-сайти, які ми бачили [6]. Також використання соціальних мереж $\epsilon$ менш ресурсозатратним порівняно з іншими формами. Переважна більшість організацій мають офіційні сторінки в соціальних мережах, у яких акцент робиться на зворотному зв'язку з віруючими, а відтак, збільшуються можливості корегування PR-кампанії відповідно до реакції аудиторії. Водночас актуальним каналом $є$ релігійні інтернет-ресурси, спрямовані на висвітлення діяльності релігійних організацій на позаконфесійній основі, а також наукові заходи релігієзнавчого спрямування. До таких ресурсів нині належать "Релігія в Україні", "Релігійно-інформаційна служба України".

Специфікою діяльності релігійних організацій $\epsilon$ спрямованість на діалог, тому "диджиталізований PR" та "Інтернет-PR" як складові PR-діяльності здійснюється переважно формально, у той час як "cluetrain-PR" набуває суттєвого поширення, навіть спостерігається тенденція витіснення цього виду діяльності інших. 
Протягом останніх десятиліть спостерігається збільшення інтенсивності інтеркультурної релігійної взаємодії, що пов'язане з розширенням мережі міжнародних мас-медіа завдяки впровадженню технологій супутникового зв'язку та Інтернету. Це дозволило релігійним організаціям упровадити транснаціональні PR-дії, найбільш поширеною з яких є трансляція богослужінь наживо з одного релігійного центру на різні країни. Як для українських, так i для польських віруючих це передусім стосується трансляцій з Єрусалиму Сходження Благодатного вогню та Великодні богослужіння з Ватикану. При чому в Україні трансляція богослужінь і православної, і католицької церков здійснюється загальнонаціональними каналами на паритетних засадах. Така PR-діяльність дозволяє не лише інтегрувати віруючих однієї конфесії в процес здійснення обряду, а й на метасоціальному рівні сприяти міжрелігійному діалогу. У цьому аспекті український досвід $\epsilon$ якісно відмінним від польського. Інтеркультурна релігійна взаємодія має в Польщі більш формальний характер, що спричинене малою кількістю віруючих різних релігій щодо римо-католиків. Так, за статистикою, у 2017 році римо-католиками себе ідентифікували майже 33 млн. віруючих, у той час як греко-католиками - 55 тис., православних понад 500 тис., протестантів - понад 60 тис., мусульман - понад 6 тис. [9, с. 196-197]. При збереженні паритетності релігійних прав і свобод у польському суспільстві, що виражається зокрема у виділенні ефірного часу на суспільних телеканалах представникам різних релігій та конфесій, це незначною мірою впливає на аудиторію.

Аналіз PR-діяльності релігійних організацій України та Польщі в контексті загальносвітових тенденцій дозволяє стверджувати, що вона здійснюється з використанням багатьох ресурсів та сучасних медіатехнологій, хоча й спостерігається брак системності. Але секуляризаційні процеси, утвердження принципу споживацтва виявляють зниження їх ефективності, поступаючись часто агресивним впливам PR-діяльності комерційних організацій з їх утилітарною спрямованістю. Про це свідчить зменшення частки релігійних програм в ефірах національних недержавних телеканалів та радіостанцій. Це актуалізує проблему використання інструментів комерційного PR релігійними організаціями, що стане предметом наших подальших досліджень.

Висновки та перспективи подальших досліджень. PR-діяльність релігійних організацій постає засобом впливу на соціальні процеси задля діалогу між ланками суспільства 3 метою досягнення громадянського консенсусу, вона складається з комплексу конкретних PR-дій, метою яких є забезпечення оптимальної взаємодії релігійної організації з громадськістю. PRдіяльність релігійних організацій цілеспрямовано створює ілюзію всепроглядності через безперервну онлайн-трансляцію релігійних установ та богослужінь. PR-діяльність має дві спрямованості: на прихильників церкви та громадськість загалом. Складовою PR-діяльності релігійних організацій є PR-діяльність у сфері культури, яка реалізується у двох аспектах: як меценатство та як інтеркультурна масова комунікація. PR-діяльність релігійних організацій здійснюється багатоканально. Основними каналами масової комунікації в PR-діяльності релігійних організацій, як і багатьох інших видів діяльності, виступають телебачення та Інтернет-ресурси, зокрема ютуб-канали, які $\epsilon$ менш ресурсозатратними на відміну від телебачення й мають значну розгалужену регіональну мережу.

\section{Список використаних джерел та літератури}

1. Andrzej Duda $z$ córka $w$ kościele. Ale Kinga wyglada! 2019-04-20 URL:https://www.fakt.pl/wydarzenia/polityka/wielkanoc-kinga-duda-i-andrzej-duda-zeswieconka/bhzr3cw\#slajd-1 (дата звернення: 18.08.2019).

2. Grunig J. E., Hunt T. Managing public relations [3rd ed.]. New York : Holt, Rinehart and Winston, 1984. $550 \mathrm{p}$.

3. Habermas J. Religion in der Öffentlichkeit. Kognitive Voraussetzungen für den "öffentlichen Vernunftgebrauch" religiöser und säkularer Bürger. In Zwischen Naturalismus und Religion. Frankfurt a. M. : Verlag Suhrkamp, 2005. S. 119-154. 
4. Hammer S. Öffentliche Religionen zwischen Kulturalismus und säkularer Vernunft. In Europa mit oder ohne Religion? [Appel / Guanzini (Hrsg.)]. Wien : V\&R unipress, 2016. S. 167-180.

5. Interkulturelle Öffentlichkeitsarbeit. Arbeitshilfe für die Ansprache von Migrantinnen und Migranten mit Behinderung [Herausgeber: Stadtimpuls gemeinnützige Gesellschaft zur Förderung und Ansiedelung sozialer Projekte mbH], Berlin, 2012. 40 S.

6. Levine R., Locke C., Weinberger D. The Cluetrain Manifesto. URL:https://cluetrain.com/ (дата звернення: 18.08.2019).

7. Merle K. Religion in der Öffentlichkeit: Digitalisierung als Herausforderung für kirchliche Kommunikationskulturen. Berlin : De Gruyter, 2019. 534 S.

8. O TBN Polska. URL:https://www.tbnpolska.tv/o-tbn (дата звернення: 18.08.2019).

9. Rocznik Statystyczny Rzeczypospolitej Polskiej [Główny Urząd Statystyczny, Departament Opracowań Statystycznych] / Redaktor Główny Dominik Rozkrut. Warszawa, 2018. 913 s.

10. Slusar W. "Планшетное сознание" как субъективная составляющая "рационального насилия" в глобализированном мире. Studia Warmińskie. 2015. № 52. S. 51-61.

11. В УГКЦ створено Патріариу раду соџіальних комунікачій УГКЦ. 9 травня 2019 URL:http://news.ugcc.ua/news/v_ugkts_stvoreno_patr\%D1\%96arshu_radu_sots\%D1\%96alnoi_komun\% D1\%96kats\%D1\%96i_ugkts_86231.html (дата звернення: 18.08.2019).

12. Кримський С. Діяльність В Філософський енииклопедичний словник / НАН України, Ін-т філософії імені Г. С. Сковороди; [редкол.: В. І. Шинкарук (голова) та ін.]. Київ : Абрис, 2002. С. 163-164.

13. Мойсеєв В. А. Паблік рілейшнз. К.: Академвидав, 2007. 224 с.

14. Огурцов А. П., Юдин Э. Г. Деятельность. В Новая философская энциклопедия: В 4 т./ Ин-т философии РАН, Нац. общ.-научн. фонд; Научно ред. совет: предс. В. С. Степин. М. : Мысль, 2010. T. 1. C. 633-634.

15. Пархонюк Т. М. Релігійне телебачення в Україні: еволюція та перспективи Наукові записки Національного університету "Острозька академія". Серія: Релігієзнавство. 2016. Вип. 1. С. 44-57.

16. Слюсар В. М. Насилля: соиіально-філософська природа. Житомир: Вид-во Свенок О. О., 2017. $450 \mathrm{c}$.

17. Солодов В. РR-деятельность Римской католической церкви: пример Франции.- 10.01.2005. URL:http://propr.com.ua/ru/public/view/10643 (дата звернення: 18.08.2019).

18. Шишкин Д. П., Гавра Д. П., Бровко С. Л. РR-кампании: методология и технология. СПб. : Роза мира, 2004. 187 с.

19. Ющенко та Янукович привітали українців 3 Великоднем. 19 квітня 2009 p. URL:https://podrobnosti.ua/597258-juschenko-ta-janukovich-privtali-ukrantsv-z-velikodnem.html_ (дата звернення: 18.08.2019).

\section{References (translated \& transliterated)}

1. Andrzej Duda z córka w kościele. Ale Kinga wyglada! (2019). [Andrzej Duda with his daughter in the church. But Kinga looks!] - 2019-04-20 // https://www.fakt.pl/wydarzenia/polityka/wielkanoc-kingaduda-i-andrzej-duda-ze-swieconka/bhzr3cw\#slajd-1 [in Polish].

2. Grunig, J. E., Hunt, T. (1984). Managing public relations. New York: Holt, Rinehart and Winston. [in English].

3. Habermas, J. (2005). Religion in der Öffentlichkeit. Kognitive Voraussetzungen für den "öffentlichen Vernunftgebrauch" religiöser und säkularer Bürger [Religion in public. Cognitive prerequisites for the "public use of reason" of religious and secular citizens]. in Habermas, J. Zwischen Naturalismus und Religion. Frankfurt a. M.: Verlag Suhrkamp. 119 - 154. [in German].

4. Hammer, S. (2016). Öffentliche Religionen zwischen Kulturalismus und säkularer Vernunft [Public religions between culturalism and secular reason]. in Europa mit oder ohne Religion? [Appel / Guanzini (Hrsg.)]. - Wien: V\&R unipress. 167-180. [in German].

5. Interkulturelle Öffentlichkeitsarbeit. Arbeitshilfe für die Ansprache von Migrantinnen und Migranten mit Behinderung (2012). [Intercultural public relations. Working aid for addressing migrants with disabilities]. Berlin. [in German].

6. Levine, R., Locke, Ch., Weinberger, D. The Cluetrain Manifesto The Cluetrain Manifesto // https://cluetrain.com/ [in English].

7. Merle, K. (2019). Religion in der Öffentlichkeit: Digitalisierung als Herausforderung für kirchliche Kommunikationskulturen [Religion in public: digitization as a challenge for church communication cultures]. Berlin: De Gruyter. [in German].

8. O TBN Polska // https://www.tbnpolska.tv/o-tbn [in Polish]. 
9. Rocznik Statystyczny Rzeczypospolitej Polskiej (2018). [Statistical Yearbook of the Republic of Poland] [Główny Urząd Statystyczny, Departament Opracowań Statystycznych]/ Redaktor Główny Dominik Rozkrut. Warszawa. [in Polish].

10. Slusar, W. (2015). "Планшетное сознание" как субъективная составляющая "рационального насилия" в глобализированном мире [Tablet consciousness "as the subjective component of" rational violence "in a globalized world]. Studia Warmińskie. 52. 51-61. [in Russian].

11. V UHKTs stvoreno Patriarshu radu sotsialnykh komunikatsii UHKTs (2019). [The Patriarchate of the Socialist Communities of the UGCC was organized at the UGCC]. 9 travnia: http://news.ugcc.ua/news/v ugkts stvoreno_patr\%D1\%96arshu_radu_sots\%D1\%96alnoi_komun\%D1\%9 6kats\%D1\%96i ugkts 86231.html/[in Ukrainian].

12. Krymskyi, S. (2002). Diialnist [Activity] in Filosofskyi entsyklopedychnyi slovnyk / NAN Ukrainy, In-t filosofii imeni H. S. Skovorody; [redkol.: V. I. Shynkaruk (holova) ta in.]. Kyiv: Abrys. 163-164. [in Ukrainian].

13. Moiseiev, V. A. (2007). Pablik rileishnz [PR]. K.: Akademvydav. [in Ukrainian].

14. Ogurcov, A. P., Yudin, E. G. (2010). Deyatel'nost' [Activity]. In Novaya filosofskaya enciklopediya: V 4 t. / In-t filosofii RAN, Nac. obshch.-nauchn. fond; Nauchno red. sovet: preds. V. S. Stepin. - M.: Mysl', T. 1. 633-634. [in Russian]

15. Parkhoniuk, T. M. (2016). Relihiine telebachennia v Ukraini: evoliutsiia ta perspektyvy [Religion of the television tower in Ukraine: evolutions and prospects]. Naukovi zapysky Natsionalnoho universytetu "Ostrozka akademiia". Seriia: Relihiieznavstvo. Vyp. 1. 44-57. [in Ukrainian].

16. Sliusar, V. M. (2017). Nasyllia: sotsialno-filosofska pryroda [Violence: socio-philosophical nature]. Zhytomyr: Vyd-vo Yevenok O. O. [in Ukrainian].

17. Solodov, V. (2005). PR-deiatelnost Rymskoi katolycheskoi tserkvy: prymer Frantsyy [PR-activity of the Roman Catholic Church: an example of France.] . 10.01.2005. / V. Solodov // http://propr.com.ua/ru/public/view/10643/[in Russian]

18. Shyshkyn, D. P., Havra, D. P., Brovko, S. L. (2004). PR-kampanyy: metodolohyia y tekhnolohyia [PR campaigns: methodology and technology]. SPb.: Roza myra. [in Russian].

19. Iushchenko ta Yanukovych pryvitaly ukraintsiv z Velykodnem (2009). [Yushchenko and Yanukovych congratulated Ukrainians on Easter.]. 19 kvitnia 2009 r.: https://podrobnosti.ua/597258-juschenko-tajanukovich-privtali-ukrantsv-z-velikodnem.html/ [in Ukrainian].

Статтю отримано 17.09.2019 року

Прийнято до друку 22.10.2019 року 